\title{
SHERMAN ACT CONSPIRACY THEORY IN RESALE PRICE MAINTENANCE CASES
}

In Klein v. American Luggage Works' a retailer was cut off by a manufacturer for failing to maintain retail prices. The retailer sued not only the manufacturer but also competing retail dealers who maintained prices, for treble damages under the Sherman ${ }^{2}$ and Clayton ${ }^{3}$ Acts. Judgment was rendered against all defendants. The reasoning of the court reflects the confusion in conspiracy theory in this branch of the law, and demonstrates that this confusion is having prejudicial effects on the administration of justice.

The principal problem stems from the fact that two different concepts of what constitutes a "restraint of trade" have developed in resale price maintenance cases. Most courts in defining restraints take the view that the ultimate purpose of the Sherman Act is the prevention of uncompetitive results and the preservation for the consumer of benefits of free competition. $4 \mathrm{~A}$ small group of cases, however, beginning with United States v. Colgate \& Co.5 and ending with Frey \& Son v. Cudahy Packing Co., 6 treat the purpose of the act as the prohibition of certain methods which in their normal operation impair competition. The first part of this comment will trace the origins of these two concepts. The second part will deal with the confusion in the application of conspiracy theory which has resulted from a failure to distinguish the two concepts properly.

\section{I}

The application of Sherman Act conspiracy theory by the Supreme Court to resale price maintenance cases began with Dr. Miles Medical Co. v. John

1206 F. Supp. 924 (D. Del. 1962).

226 Stat. 209 (1890), 15 U.S.C. $\$ 1$ (1958): "Every contract, combination in the form of trust or otherwise, or conspiracy, in restraint of trade or commerce among the several States, or with foreign nations, is declared to be illegal ...."

338 Stat. 731 (1914), 15 U.S.C. $\$ 15$ (1958): “Any person who shall be injured in his business or property by reason of anything forbidden in the antitrust laws may sue therefor in any district court ... and shall recover threefold the damages by him sustained, and the cost of suit, including a reasonable attorney's fee."

4 United States v. Parke, Davis \& Co., 362 U.S. 29 (1960); United States v. Bausch \& Lomb Optical Co., 321 U.S. 707 (1944); FTC v. Beech-Nut Packing Co., 257 U.S. 441 (1922); Dr. Miles Medical Co. v. John D. Park \& Sons Co., 220 U.S. 373 (1911); Shakespeare Co. v. FTC, 50 F.2d 758 (6th Cir. 1931); Cream of Wheat Co. v. FTC, 14 F.2d 40 (8th Cir. 1926); Hills Bros. v. FTC, 9 F.2d 481 (9th Cir. 1926); Q.R.S. Music Co. v. FTC, 12 F.2d 730 (7th Cir. 1926); Toledo Pipe-Threading Mach. Co. v. FTC, 11 F.2d 337 (6th Cir. 1926); Oppenheim, Oberndorf \& Co. v. FTC, 5 F.2d 574 (4th Cir. 1925).

5250 U.S. 300 (1919).

6 Frey \& Son, Inc. v. Cudahy Packing Co., 256 U.S. 208 (1921); United States v. A. Schrader's Son, Inc., 252 U.S. 85 (1920); United States v. Colgate \& Co., 250 U.S. 300 (1919). 
D. Park \& Sons Co.7 That case dealt with the validity of a series of contracts between a manufacturer and his dealers which required maintenance of resale prices. ${ }^{8}$ The question of horizontal agreements to fix prices had already been before the Court, 9 and it appears to have been assumed in the Dr. Miles opinion that such arrangements were illegal per se.10 Reasoning from this basis, the Court found that the contracts were illegal because these individual, vertical contracts accomplished the same results that a horizontal agreement between the individual dealers would have accomplished, i.e., the fixing of a uniform price to the public:

[C]omplainant can fare no better with its plan of identical contracts than could the dealers themselves if they formed a combination and endeavored to establish the same restrictions, and thus to achieve the same result, by agreement with each other. ${ }^{11}$

The Court indicated that its result was based upon an interpretation of the act in which the immediate purpose was the preservation for the public of the benefits of free competition: "[T] he public is entitled to whatever advantage may be derived from competition in subsequent traffic."12 By Dr. Miles standards, therefore, the legality of an agreement made by the manufacturer with a dealer was determined by its effect upon the public. If it resulted in a uniformity of price similar to that achieved by horizontal price fixing, then the arrangement was illegal.

Seven years later, however, this position was reconsidered in United States v. Colgate \& Co.13 That case involved a resale price maintenance plan which was enforced by the manufacturer's prior announcement that he would refuse further dealings with any dealer who cut prices. Mr. Justice McReynolds, delivering the opinion of the Court, found this system legal because of the basic

7220 U.S. 373 (1911).

$s$ The manufacturer was seeking damages for interference with these contracts by a third party. The Court did not consider whether if the contract had been valid, it would have been protected against induced breach. $C f$. Sunbeam Corp. v. Masters of Miami, Inc., 225 F.2d 191 (5th Cir. 1955); Sunbeam Corp. v. Payless Drug Stores, 113 F. Supp. 31 (N.D. Cal. 1953); Schapiro, The German Law Against Restraints of Competition, 62 CoLUM. L. REv. 1, 201 (1962); Levi, The Parke, Davis-Colgate Doctrine: The Ban on Resale Price Maintenance, 1960 SUP. CT. REv. 258.

9 Addyston Pipe \& Steel Co. v. United States, 175 U.S. 211 (1899).

10220 U.S. at 408; see also Levi, supra note 8, at 268. The issue of whether horizontal price fixing might be legal if reasonable was not, however, definitively settled until the case of United States v. Trenton Potteries Co., 273 U.S. 392 (1927), which held such arrangements illegal per se. On this topic see generally Comment, The Per Se Illegality of Price-FixingSans Power, Purpose, or Effect, 19 U. CHI. L. REv. 837 (1952).

11220 U.S. at 408.

$12 \mathrm{Id}$. at 409 ; see also id. at 406 .

13250 U.S. 300 (1919). 
right of the merchant to deal, or refuse to deal, with whom he pleases. ${ }^{14}$ Much confusion had arisen as to how Colgate altered Dr. Miles. This confusion resulted from Mr. Justice McReynolds' treatment of Dr. Miles. ${ }^{15} \mathrm{Dr}$. Miles was distinguished because "the unlawful combination was effected through contracts which undertook to prevent dealers from freely exercising the right to sell."'16 This statement, along with later decisions by the same Justice, led many to assume that the only basis for distinction was the existence of binding contracts in Dr. Miles. 17 In reality, Mr. Justice McReynolds seems to

14 It has been suggested that this is a constitutional right. Grenada Lumber Co. v. Mississippi, 217 U.S. 433 (1910) (concerning right of dealers to refuse to deal with manufacturer); see also Levi, supra note 8, at 284; cf. FTC v. Raymond Bros.-Clark Co., 263 U.S. 565 (1924). But compare United States v. New York Great Atl. \& Pac. Tea Co., 173 F.2d 79,87 (7th Cir. 1949), perhaps an aberration in this as well as other respects; cf. Levi, supra note 8 , at 289 n.165. The problem of reconciling freedom of contract (or, more often, freedom not to contract) with the prohibitions of antitrust law often received attention in early Supreme Court decisions. Eastern States Lumber Ass'n v. United States, 234 U.S. 600, 614 (1914); Standard Oil Co. v. United States, 221 U.S. 1, 56 (1911); United States v. American Tobacco Co., 221 U.S. 106, 180 (1911); United States v. Trans-Missouri Freight Ass'n, 166 U.S. 290, 320 (1897)). It has continued to be a thorny problem to the present time. Compare Bergen Drug Co. v. Parke, Davis \& Co., 307 F.2d 725 (3d Cir. 1962) (defendant in antitrust suit enjoined from refusing to deal with plaintiff during suit), with House of Materials, Inc. v. Simplicity Pattern Co., 298 F.2d 867 (2d Cir. 1962) (defendant in antitrust suit held entitled to refuse to deal with plaintiff). $C f$. White Motor Co. v. United States, 372 U.S. 253 (1963).

15 The confusion continues to exist, and is exemplified in United States v. Parke, Davis \& Co., 362 U.S. 29 (1960), where Mr. Justice Harlan in dissent takes sharp issue with the majority interpretation of the Colgate doctrine: "Until today I had not supposed that any informed antitrust practitioner or judge would have had to await Beech-Nut to know that the concerted action proscribed by the Sherman Act need not amount to a contractual agreement." Id. at 52.

16250 U.S. at 307-08.

$17 \mathrm{Mr}$. Justice McReynolds was somewhat ambiguous on whether or not he actually required a formal contract in order to find a violation of the act. In Colgate, United States v. A. Schrader's Son, Inc., 252 U.S. 85 (1920), and Frey \& Son, Inc. v. Cudahy Packing Co., 256 U.S. 208 (1921), Mr. Justice McReynolds spoke only in terms of "agreements" or "binding agreements." It is conceivable, therefore, that by "binding agreements" he meant agreements which are enforced by extra-judicial methods such as blacklists and secondary boycotts, for if he meant agreements binding only through the courts, he could have used "contracts" much more easily.

Mr. Justice McReynolds' dissent in FTC v. Beech-Nut Packing Co., 257 U.S. 441, 458 (1922), only compounded the confusion by an unfortunately loose use (for the first time) of the word "contract." The agreed statement of facts before the Court contained the following provision: "That the merchandising conduct of respondent heretofore defined and as herein involved does not constitute a contract or contracts whereby resale prices are fixed, maintained, and enforced." Id. at 458. Mr. Justice McReynolds seized upon this as the basis for his dissent: "If the solemn stipulation did not expressly negative the existence of contracts amongst the parties to maintain prices, I should think the detailed facts sufficient to support a finding that there were such agreements. But starting with that plain negation I can find no adequate grounds for condemning the respondent." Id. at 458 . He amplifies this statement later: "How can there be methods of cooperation, cooperative methods, an undertaking to prevent others, or the cooperation of customers with a view to prevent others [all terms used in the opinion of the Court], when the existence of the essential contracts is definitely excluded?" Id. at 459. Mr. Justice McReynolds cannot possibly be using "contracts" in its 
have viewed the purpose of the act as being the protection of the trader from unfair restraints in the conduct of his business, rather than the protection of the public from increased prices resulting from elimination of competition as in Dr. Miles. This emphasis is amply demonstrated in his own words:

The purpose of the Sherman Act is to prohibit monopolies, contracts and combinations which probably would unduly interfere with the free exercise of their rights by those engaged, or who wish to engage, in trade and commerce-in a word to preserve the right of freedom to trade. 18

Thus it can be seen that the true effect of Colgate was to abolish the Dr. Miles test of elimination of competition. The new test of legality was whether the methods by which an arrangement is enforced infringed unduly on the freedom of the trader.

In the following years it became clear that not everyone understood the thrust of Mr. Justice McReynolds' analysis. ${ }^{19}$ FTC v. Beech-Nut Packing Co.20 shows that the other Justices on the Supreme Court shared the confusion. In Beech-Nut prices were maintained by a complicated policing system. Its basic elements were: Refusal to sell to wholesale and resale dealers who did not maintain resale prices, or who resold to dealers who did not maintain prices; persuading retailers not to buy from wholesale dealers who did not maintain

technical sense in these statements. In the first he uses "contracts" and "agreements" interchangeably-the question being thus which term he is using incorrectly, since they are by no interpretation legally synonymous. The second statement seems to confirm that "contracts" is the incorrect term; for certainly Mr. Justice McReynolds cannot have thought that people cannot cooperate with each other without legal contracts. Moreover, if he really were only concerned with written agreements enforceable at law he would not have needed to seize upon the agreed statement of facts to support his conclusion; for the whole theory of the case rested on unwritten arrangements and no formal agreement was mentioned or alleged. Clearly, therefore, "contracts" in this sense is being used in the sense of the much less formal "agreements," an interpretation which is in better harmony with Mr. Justice McReynolds" earlier decisions.

18250 U.S. at 307. Mr. Justice McReynolds appears to stress this factor in other types of antitrust cases as well. See Paramount Famous Lasky Corp. v. United States, 282 U.S. 30, 41 (1930) (horizontal conspiracy); United States v. American Linseed Oil Co., 262 U.S. 371, 389 (1923) (horizontal conspiracy); FTC v. Sinclair Refining Co., 262 U.S. 463, 474 (1923) (horizontal conspiracy and unfair methods of competition under the Federal Trade Commission Act). A suggestion of a similar conception of the Sherman Act appears in KieferStewart Co. v. Joseph E. Seagram \& Sons, Inc. 340 U.S. 211, 213 (1951). Compare Levi, supra note 8, at 270-78; Northern Securities Co. v. United States, 193 U.S. 197, 400 (1904) (Holmes, J., dissenting).

19 E.g., United States v. A. Schrader's Son, Inc., 264 Fed. 175 (N.D. Ohio 1919), rev'd, 252 U.S. 85 (1920) (holding resale price maintenance scheme valid): "Personally, and with all due respect, permit me to say that I can see no real difference upon the facts between the Dr. Miles Medical Company Case and the Colgate Company Case." 264 Fed. at 183. The circuit court of appeals in Cudahy Packing Co. v. Frey \& Son, Inc., 261 Fed. 65 (4th Cir. 1919), aff'd,256 U.S. 208 (1921), interpreted Colgate in such a way as to draw the disapproval of both the majority, 256 U.S. at 210 , and the minority, $i d$. at 312, opinions of the Supreme Court.

20257 U.S. 441 (1922). 
resale prices or who sold to price cutters; use of dealers to police and report on price cutters; blacklists of price cutters; and use of code numbers on products so that an offending dealer could be traced.21 This system thus enmeshed both wholesalers and retailers in a scheme to set prices at two levels of distribution subsequent to the manufacturer. The test the Court applied to this system was one of legality of methods, taken directly from Colgate:

[I]t is settled that in prosecutions under the Sherman Act a trader is not guilty of violating its terms who simply refuses to sell to others, and he may withhold his goods from those who will not sell them at the prices which he fixes for their resale. He may not, consistently with the act, go beyond the exercise of this right, and by contracts or combinations, expressed or implied, unduly hinder or obstruct the free and natural flow of commerce in the channels of interstate trade. 22

The Court then confused matters by finding a violation not because freedom of the trader was restricted, but because competition was eliminated: "From this course of conduct a court may infer, indeed cannot escape the conclusion, that competition among retail distributors is practically suppressed." 23 This statement creates confusion because by the Colgate test of methods the elimination of competition was not a relevant consideration. The establishment of uniform prices at a given level of distribution must always result in the elimination of competition between dealers in that product. Colgate was tolerant of that result so long as the dealers did not appear to have been unduly restricted in their actions by the manufacturer's methods of enforcement.

Aside from mixing Colgate and Dr. Miles standards, Beech-Nut modified the Colgate approach in attempting to apply it. The Court, in affirming, limited the order of the Federal Trade Commission condemning Beech-Nut's practices:

We are, however, of the opinion that the order of the Commission is too broad. The order should have required the company to cease and desist from carrying into effect its so-called Beech-Nut Policy by cooperative methods in which the respondent and its distributors, customers and agents undertake to prevent others from obtaining the company's products at less than the prices designated by it . ...24

The following specific practices were prohibited: Reporting by dealers on price-cutters, blacklisting, diverting retail orders from noncomplying wholesalers, coding products so that they could be traced through the system of distribution, and a final general clause, "utilizing any other equivalent cooperative means of accomplishing the maintenance of prices fixed by the company."25

$21 \mathrm{Id}$. at 456.
$22 \mathrm{Id}$. at $452-53$.
$23 \mathrm{Id}$. at 455 .
${ }^{24} \mathrm{Id}$. at $455-56$.
$25 \mathrm{Id}$. at 456. 
Thus while the approach of determining the legality of the scheme according to the legality of the methods by which it is established was continued, the illegal methods after Beech-Nut were those requiring cooperation between the dealers and the manufacturer as well as those restricting freedom of the trader by enforceable agreement.

Later cases followed the Beech-Nut reasoning, frequently in almost identical language. ${ }^{26}$ Beech-Nut came to be interpreted as reasserting the consumeroriented view of the act, while still recognizing Colgate as having created a small exception to the general prohibition against price-fixing in those cases where price fixing was enforced by mere prior threats of refusal to deal.27 Even if this interpretation of the case is accepted, however, it must be emphasized that Beech-Nut did not change the Colgate approach of examining methods of enforcement. The use of a standard which looks to methods of enforcement may indeed have been compelled by the language of the act itself. Section 1 of the act reaches only "contracts, combinations, and conspiracies." A total overruling of Colgate, however ardently desired by some, 28

${ }^{26}$ Shakespeare Co. v. FTC, 50 F.2d 758 (6th Cir. 1931); Cream of Wheat Co. v. FTC, 14 F.2d 40 (8th Cir. 1926); Hills Bros. v. FTC, 9 F.2d 481 (9th Cir. 1926); Moir v. FTC, 12 F.2d 22 (1st Cir. 1926); Q.R.S. Music Co. v. FTC, 12 F.2d 730 (7th Cir. 1926); Toledo Pipe-Threading Mach. Co. v. FTC, 11 F.2d 337 (6th Cir. 1926); Oppenheim, Oberndorf \& Co. v. FTC, 5 F.2d 574 (4th Cir. 1925).

27 United States v. Bausch \& Lomb Optical Co., 321 U.S. 707, 721 (1944) (dictum). The Colgate case was also cited approvingly in Klor's, Inc. v. Broadway-Hale Stores, 359 U.S. 207, 212 (1959); Times-Picayune Publishing Co. v. United States, 345 U.S. 594, 625 (1952); Ethyl Gasoline Corp. v. United States, 309 U.S. 436, 457 (1940); cf. Lorain Journal Co. v. United States, 342 U.S. 143, 155 (1951). But cf. Kiefer-Stewart Co. v. Joseph E. Seagram \& Sons, Inc., 340 U.S. 211, 214 (1950); see also United States v. Freuhauf, 365 U.S. 146, 158 (1961); FTC v. Simplicity Pattern Co., 360 U.S. 55, 64 (1959). Price maintenance arrangements were allowed to survive in Harriet Hubbard Ayer v. FTC, 15 F.2d 274 (2d Cir. 1920) (per Manton and Hough, JJ., L. Hand, J., dissenting without opinion); and in two postBeech-Nut decisions by Judge A. N. Hand, Adams-Mitchell Co. v. Cambridge Distrib. Co., 189 F.2d 913 (2d Cir. 1951); United States v. Hudnut, 8 F.2d 1010 (S.D.N.Y. 1925). Earlier, Judge A. N. Hand had declined to anticipate Beech-Nut. Baran v. Goodyear Tire \& Rubber Co., 256 Fed. 571 (S.D.N.Y. 1919). He joined, however, in J.W. Kobi v. FTC, 5 F.2d 574 (4th Cir. 1925), and in Connecticut Importing Co. v. Continental Distilling Corp., 129 F.2d 651 (2d Cir. 1942), applying Beech-Nut, and declined to join the Second Circuit's opinion in the dubious case of American Tobacco Co. v. FTC, 9 F.2d 570 (2d Cir. 1925), aff'd, 274 U.S. 543 (1927).

${ }^{28}$ See Turner, The Definition of Agreement Under the Sherman Act: Conscious Parallelism and Refusals to Deal, 75 HARv. L. Rev. 655 (1962); Comment, 58 YALE L.J. 1121, 1141 (1959). Professor Turner would dispose of Colgate by holding that a manufacturer enters into an agreement with retailers when he uses the threat to refuse to deal to induce them to acquiesce in maintaining a resale price. Thus the manufacturer retains the "right" to announce a price and to refuse to deal, but adherence to the announced price is rendered illegal and creates the requisite conspiracy. "[A] policy of refusing to deal with price cutters is no more nor less than an invitation to agree on resale price which, if it produces the desired acquiescence in a minimum price, results in unlawful agreements." Turner, supra at 689. The court in Klein v. American Luggage Works, 206 F. Supp. 924 (D. Del. 1962), restated the proposition: "In the face of an advance announcement by the manufacturer that price 
might have overlooked the need which section 1 imposes for a second participant in the illegal act. Section 2, to be sure, imposes no such requirement. But it does impose a market power and intent test, and it would have been disingenuous at best to condemn as "monopolistic" practices which redound to the primary benefit, not of the "monopolist," but of his dealers. 29

Thus, although illegality derived from the fixing of prices, the manufacturer might still after Beech-Nut avoid the sanctions of the act by using methods within the scope of Colgate protection. Therefore the courts were required to first determine whether prices were in fact fixed, and then to see whether the manufacturer fitted within the exception of Colgate. Whether or not the manufacturer had done so was to be determined by examining the methods used to enforce his plan, so that even after Beech-Nut the methods of the

cutters will be denied supply, a seller's compliance with prices suggested strongly infers a tacit or implied resale price maintenance agreement." Id. at 937.

As to coerced compliance, Professor Turner sees no difference between coercion of a dealer into following a minimum price and coercion of him "into a contractual commitment to do so ... successful insistence on resale price maintenance, enforced by a threat of refusal to deal, involves no serious question as to whether the concept of agreement is being stretched out of joint to cover it." Turner, supra at 688. "[T] he conclusion that the coerced parties are themselves violators may help prevent violations by stiffening the backs of those whom the principal culprit seeks to coerce." Id. at 702. Indeed it would; one can irreverently observe that under the Turner rule the best way for a manufacturer to ensure noncompliance with a desired price would be to announce that he intended to exercise his Colgate rights.

Professor Turner, however, would find tacit agreement only when "but for the manufacturer's declaration of policy,.... [the distributor] would sell for less." $I d$. at 688 . Thus the retailers in Klein, unlike the chain drug companies induced to raise prices in Parke, Davis, might not be parties to a conspiracy even under Professor Turner's view. For we are told that "in the formulation of ... prices ... the needs of department stores were explicitly considered ..., compliance on the part of department stores was automatically assured by virtue of their profit margin requirements." 206 F. Supp. at 930. Perhaps the Turner view would have made liability in Klein turn on whether the department stores would have continued to sell American luggage at a lower, more competitive price, absent the price maintenance program, rather than abandoning the line or continuing to sell at prices reflecting normal margins. But this may not be so, for we are told that the demise of Colgate would "eliminat[e] irrational or unworkable distinctions." Turner, supra at 706.

29 Professor Turner attempts to escape this objection for some cases by observing "the purpose in stabilizing retail prices may plainly be to enable ... producers to protect noncompetitive oligopoly pricing at the manufacturer's level from the disruptions caused by the varying price decisions of distributors; but regardless of their purpose, adoption of fair trade is virtually certain to have this anticompetitive effect . ... It might therefore seem reasonable to say that each individual oligopolist either 'attempting to monopolize' (where the purpose is plain) or 'monopolizing' in violation of section 2." Turner, supra note 28, at 679-80. The case postulated is one in which "discount houses have been accounting for upwards of forty per cent of the sales of electric razors"; it is suggested that "advantages of consciously parallel behavior" apart from agreement may induce all manufacturers to price maintain though it would otherwise be in the interest of no one of them to do so. The advantages to the manufacturers seem too evanescent to be described as "monopoly," absent an actual agreement, since advocates of price maintenance can urge not unconvincingly that where the percentage of the market held by low-cost distributors is so large, the temptations of the market will adequately check exploitation of any advantages that may inhere in parallel conduct. 
manufacturer were still the primary source of the offense. United States $v$. Parke, Davis \& Co.30 illustrates the dangers of failing to make such a distinction between results and methods.

On its facts, Parke, Davis was similar enough to Beech-Nut to have been decided without making any alteration in the Beech-Nut doctrine. Parke, Davis had a system of resale price maintenance at both the wholesale and retail levels. In an effort to stop recurrent retail price-cutting in its Virginia territory, the company threatened to refuse to deal with wholesalers who supplied price-cutting retailers. 31 This intertwining of wholesalers and retailers in the same plan would have been sufficient to find the plan illegal under Beech-Nut, and the Court in fact did so. 32 But it continued beyond that point and found additional illegality in the manufacturer's efforts to induce compliance at the retail level by assuring retailers that their competitors would be made to maintain prices. ${ }^{33}$ The Court thus purported to alter the cooperation criterion of Beech-Nut:

[1] a manufacturer is unwilling to rely on individual self-interest to bring about general voluntary acquiescence which has the collateral effect of eliminating competition, and takes affirmative action to achieve uniform adherence by inducing each customer to adhere to avoid such price competition, the customers' acquiescence is not then a matter of individual free

30362 U.S. 29 (1959).

31 Id. at 33.

$32 \mathrm{Id}$. at 45-46. The Parke-Davis wholesaler plan differed from that in Beech-Nut in degree but not in kind. Mr. Justice Harlan, dissenting, took the view that Parke, Davis' action was wholly unilateral, and that Beech-Nut condemned only "cooperative group action." 362 U.S. at 55. The majority felt that cooperative action was present. Professor Turner has observed that "it is difficult if not impossible even for a lawyer to understand why acquiescence induced by a refusal to deal for one reason (selling to price-cutting retailers) should make the conduct any more an 'agreement' than is acquiescence induced by a refusal to sell for a different reason (selling below the manufacturer's suggested price)." Turner, supra note 28, at 686. Perhaps the answer is to be found in the fact that not merely "acquiescence" but activity is induced in the first case: The wholesalers must spy upon and warn their dealers, rather than merely adjusting their own pricing conduct, thus supplying the basis for a combination or conspiracy. Dean Levi has suggested that the manufacturer's organization of a wholesaler "boycott" may be the factor leading to illegality, Levi, supra note 8, at 26970 , though another commentator has disputed that a true boycott is in fact involved. Robinson, Providing for Orderly Marketing of Goods. 15 A.B.A. ANTITRUST SECTION, 282, 302-03 \& n. 94 (1959).

${ }^{33}$ The Court presumably could have enjoined the manufacturer's activities at the retail level without finding that they, standing alone, were illegal, since they could be viewed as ancillary to the Beech-Nut violation. Cf. United States v. Bausch \& Lomb Optical Co., 321 U.S. 707 (1944). But the Supreme Court was not disposed toward analyzing the case in terms of the relief which would be appropriate if Parke, Davis, on remand, could make out no defense. Rather it merely directed the district court " to enter an appropriate judgment enjoining Parke-Davis from further violations of the Sherman Act." 362 U.S. at 49 . In the final event, the Government abandoned its attempt to secure an injunction and sought instead only a judgment of violation. See generally Comment, Mootness, The Parke-Davis Case and Treble Damage Claimants, 29 U. CH. L. REv. 507 (1962). 
choice prompted by the desirability of the product. The product then comes packaged in a competition free wrapping-a valuable feature in itselfby virtue of the concerted action induced by the manufacturer. 34

According to this test the actions of the manufacturer alone would determine whether or not a violation has occurred; enforceable restrictions upon or cooperation with dealers might be unnecessary. The conspiracy might be created without any actions by the customer other than continuing to deal in the product. Acquiescence in a clumsily executed price maintenance scheme, even though given under a threat to withdraw supplies, is sufficient to render the dealer a co-conspirator, and thus to supply the second participant necessary to create a conspiracy or combination forbidden under the act.

This standard is clearly not workable. The Court seems to have tried to make the test of legality the customer's reason for buying the product. The plan would become illegal when the manufacturer's actions cause the customer to buy the product because it can be sold in a competition-free market rather than because of its inherent value. The Court disregarded the fact that a dealer informed of a resale price maintenance plan by a supplier must almost certainly know that the plan will tend to eliminate competition. Any dealer desiring that competition be eliminated will consider the plan "a valuable feature in itself" and a reason for buying the product. The methods of the manufacturer are irrelevant to this consideration. The causal relationship between methods of enforcement and reasons for buying the product is thus nonexistent.

It may be said that from Dr. Miles to Parke, Davis there has been a steady evolution of the standards applied to resale price maintenance plans. Dr. Miles determined legality according to the effects on the public. Colgate changed the standard to the illegality of the methods of the manufacturer. Beech-Nut apparently sought a middle ground between the two, basing illegality on the fixing of prices, but leaving an exception to the general ban on price-fixing if the manufacturer used methods of enforcement allowed by Colgate.

From Colgate to Parke, Davis there has also been an evolution in the methods deemed illegal under Colgate. Colgate attached illegality to those methods infringing on freedom of the trader. Beech-Nut added to this the use of methods requiring cooperation between the dealers and the manufacturer. Parke, Davis deemed illegal those methods which caused the dealers to take the product because it could be resold in a noncompetitive market, rather than because of its inherent value. The following analysis will show that both of these

34362 U.S. at 46-47. Even the court in Klein expressed mild scepticism about this ingenious distinction: "The presence of ... pressures belies the inference that compliance on the part of each customer stems from individual free choice motivated solely by desire for the product-an explanation of customer conduct which the Supreme Court apparently believes more plausible when the manufacturer confines his price maintenance efforts to those permitted by Colgate." 206 F. Supp. at 939. 
trends have contributed in Parke, Davis to an alteration of the mens rea requirement of conspiracy theory, and that workable standards in this area have thus been further eroded.

II

The requirements of conspiracy theory have been loosely construed by the courts in Sherman Act cases for many years. ${ }^{35}$ The difficulty of proving criminal intent in this area has been so great that the courts have almost of necessity been liberal in their interpretation of the mens rea requirement in order to avoid emasculation of the act. ${ }^{36}$ The doctrine of these cases as it appears to have evolved today is that no showing of specific intent is necessary to prove Sherman Act conspiracy. The mens rea requirement will be fulfilled so long as the defendant intended to commit the act from which the illegal effect necessarily resulted.37 Parke, Davis, however, now can be read as allowing the formation of a conspiracy to be determined entirely by the manufacturer's actions. This innovation stretches conspiracy theory even farther, for a dealer might easily participate in a price maintenance scheme, perhaps even out of necessity, without knowledge that the manufacturer would employ tactics which exceeded Colgate protection. He would not intend that acts exceeding the bounds of Colgate (and therefore illegal) be committed, but would nevertheless be a party to the conspiracy. 38

35 The subject is treated in Developments in the Law-Criminal Conspiracy, 72 HARv. L. Rev. 920, 1000-05 (1959); Note, 62 HaRv. L. Rev. 276, 281 (1948); cf. Kadish, Some Observations on the Use of Criminal Sanctions in Enforcing Economic Regulations, $30 \mathrm{U}$. CHI. L. Rev. 423, 444 n.89 (1963). See also the concurring opinion of Mr. Justice Jackson in Krulewitch v. United States, 336 U.S. 440, 451-52 (1949), on the danger of the loose standards of civil conspiracy being employed in criminal cases.

${ }^{36}$ See United States v. Griffith, 334 U.S. 100, 105 (1948): "To require a greater showing would cripple the act."

37 United States v. Griffth, 334 U.S. 100, 105 (1948); United States v. Patten, 226 U.S. 525, 543 (1913); United States v. Reading Co., 226 U.S. 324, 370 (1912); Addyston Pipe \& Steel Co. v. United States, 175 U.S. 211, 243 (1899).

38 It is fair to observe, however, that the condemnation of the activities at the retail level in Parke, Davis may rest on the fact that Parke, Davis received assurances from dealers as well as gave them. The Court noted that "Parke-Davis sought assurances of compliance and got them as well as the compliance itself." 362 U.S. at 46 . The activities at the retail level may thus have been condemned as a simple Dr. Miles-type 'implied agreement' violation. This may explain the Parke, Davis Court's failure to cite Interstate Circuit, 306 U.S. 208 (1939), or any of the other "conscious parallelism" cases so enthusiastically cited by the court in Klein. The emphasis on the general compliance obtained may be explained by a felt need to make out the system of contracts presumably necessary to illegality under $D r$. Miles, since it is not well established that a single price maintenance contract, standing alone, is illegal. Mr. Justice Stewart's concurrence, which observed that "the present record shows an illegal combination to maintain retail prices," 362 U.S. at 49 , lends credence to this interpretation. Under this view, the Parke, Davis case adds nothing to the law; it is simply half $D r$. Miles (or more accurately United States v. A. Schrader's Son, Inc., 252 U.S. 85 (1920)) and half Beech-Nut.

But it is doubtful that the Court entered into its discussion of "substantial unanimity" merely to establish a system of contracts that would be illegal under Dr. Miles. For the Court in referring to Parke, Davis' negotiations with one dealer, made clear its belief that a 
The Court's confusion on this point can be explained most easily in terms of a failure to distinguish between the ends of the act and the Colgate exemption. The Court regards the essence of the offense as fixing prices. All those dealers who adhered to the scheme must have intended that prices be fixed. Therefore this cooperation in the most important element of the offense might seem to fulfill the mens rea requirement.

The attempt by the Parke, Davis court to make a connection between the methods of the manufacturer and the reasons of the dealers for taking the product may have been an effort to stretch conspiracy theory to fit the facts. The Court erroneously assumed that the methods of the manufacturer could be causally connected with the intention of the dealers that competition be eliminated, and thus that proof of the methods would establish the dealers' intention and thereby meet the mens rea requirement.

Klein v. American Luggage Works ${ }^{39}$ demonstrates the dangers which the errors of Parke, Davis have created.40 The plaintiff in Klein, suing under the treble damage provision of the Clayton Act, ${ }^{41}$ was a price-cutting retail dealer. The defendant-manufacturer attempted to maintain prices by informing new customers of his policy, circulating catalogs containing the resale prices, preticketing all merchandise with the desired resale prices and threatening to refuse to deal with those who did not observe the resale prices. 42 The other defendants were retailers competing with the plaintiff who maintained resale

single agreement would be illegal though standing alone. 362 U.S. at 45 n.6. The basis of this notion in prior law is not made apparent. Compare Dr. Miles Medical Co. v. John D. Park \& Sons Co., 220 U.S. 373, 411 (1911) (Holmes, J., dissenting): "I suppose that the reason why the contract is held bad is that it is part of a scheme embracing other similar contracts each of which applies to a number of similar things, with the object of fixing a general market price."

39206 F. Supp. 924 (D. Del. 1962).

40 The Klein case is noted in 62 Colum. L. Rev. 1505 (1962); 48 VA. L. Rev. 1304 (1962).

4138 Stat. 731 (1914), 15 U.S.C. $\$ 15$ (1958).

4250 Stat. 693 (1937), as amended, 15 U.S.C. $\$ 1$ (1958), amending 26 Stat. 209 (1890), provides for an exception to the general ban already cited in the form of the "fair trade" provision: "Provided That nothing contained in sections 1-7 of this title shall render illegal, contracts or agreements prescribing minimum prices for the resale of a commodity which bears, or the label or container of which bears, the trade mark, brand, or name of the producer or distributor of such commodity and which is in free and open competition with commodities of the same general class produced or distributed by others, when contracts or agreements of that description are lawful as applied to intrastate transactions under any statute, law or public policy .... in effect in any State...." The defendants in Klein failed to invoke the Delaware Fair Trade Act, DeL. CoDE ANN. tit. 6, §§ 1901-07 (1953), by way of defense, testifying that "the personal contact afforded by the system of solicitation hereinbefore described was of greater effectiveness in securing adherence to suggested resale prices than resort to Fair Trade agreements." 206 F. Supp. at 930. But the arrangement may well have been immunized by the act despite the absence of a formal contract. See United States v. Socony Mobil Oil Co., 150 F. Supp. 202 (D. Mass. 1957), appeal dismissed, 356 U.S. 925 (1958); Tobman v. Cottage Woodcraft Shop, 194 F. Supp. 83, 86-87 (S.D.Cal. 1961). The Delaware Act was upheld in another case involving Klein. General Elec. Co. v. Klein, 34 Del. Ch. 491, 106 A.2d 206 (Sup. Ct. 1954). 
prices. Judgment was rendered against all defendants, the measure of damages being the amount of loss plaintiff suffered from a forced sale of the manufacturer's product when he learned that he would no longer be supplied with it. 43

The most alarming feature of Klein is that it allows damages against the competing merchants without any specific showing that they caused plaintiff's harm, or did more than adhere to the resale prices set by the manufacturer. The defendant retailers had complained to the manufacturer's sales representative about the price cutting activities, but it is uncertain to what extent these complaints ever reached the manufacturer's headquarters. 44 The only specific finding seems to be that the price-cutting activities were discovered by the manufacturer's president while visiting plaintiff's store on other business. 45 The court did not rely on the retailers' complaints as indicating anything more than that the retailers knew that compliance with the suggested resale prices was required, 46 and the result may not depend upon the existence of

43206 F. Supp. at $945-46$. The court did not award damages for loss of anticipated profits because of questionable proof submitted by plaintiff whose claimed sales of American luggage could not be reconciled with lower total luggage sales recorded in federal excise tax returns. For an example of such damages, however, see A. C. Becken Co. v. Gemex Corp., 272 F.2d 1 (7th Cir. 1959); on this topic generally, see Clark, The Treble Damage Bonanza: New Doctrines of Damages in Private Antitrust Suits, 52 Mrch. L. Rev. 363 (1954).

44206 F. Supp. at 931 . Some report of trouble had apparently reached the manufacturer: "American's Vice President in charge of sales ... . did not recall the source of the comment; he emphatically denied that any such complaint was ever received from anyone in the employ of Wanamaker. Forman [American's sales representative] conceded that he may have reported the protests of the sales clerks to his superiors, making but oblique reference to a nameless Wilmington price cutter ...." Id. at $931 \mathrm{n} .10$.

45 The court's finding of the cause of the harm to plaintiff is as follows: "In the course of returning to Rhode Island from a social event held in Baltimore, Sol Koffler, American President, and Herman Koffer, American Vice President in charge of sales, visited Wilmington in early January of 1956. Though Wilmington was reputed to be a price cutting area, the purported purpose of the Koffler stopover was not to seek out price cutters, but rather to survey existing retailers there in an effort to ascertain whether the most desirable outlets were utilized in marketing the luggage. In the courses of this informal survey, it was learned that American luggage was available only at Klein's. Klein's display of the American line was found unattractive, and his discounting activities were discovered."Id. at 931 .

46 "[E]ach defendant retailer knew that the manufacturer expected compliance with the preticketed prices by itself and any other retailer marketing the products. Each tacitly consented to this arrangement and did in fact sell at the established prices. This conclusion is supported by the evidence of queries or comments voiced to Forman [the manufacturer's sales representative] by the respective buyers of Wanamaker and Strawbridge [the retailerdefendants] ... concerning the suspected existence of a price-cutter in the Wilmington area." Id. at 943 . The court then undertook to implicate the department stores by observing that "the two department stores thus participated in the unlawful price fixing conspiracy organized by the manufacturer with full knowledge of its concerted nature at the retail level. Moreover, they volunteered assistance in the ascertainment of noncomplying dealers, and could only have done so with the expectation that appropriate sanctions would be imposed on the offender." Id. at 943. But it was not shown that this assistance was either sought or utilized by the manufacturer, see note 45 supra. Hence it would not seem relevant unless the manufacturer's participation in a conspiracy is to be made to depend on unsolicited action by retailers. 
these complaints. The court did not expressly find that these complaints in fact caused plaintiff's harm. 47

The Klein court's reasoning follows Parke, Davis explicitly. The creation of the conspiracy is made dependent upon the manufacturer's methods alone:

This conclusion of illegality obtains because the manufacturer's resort to means beyond a prior announcement of terms sanctioned by a refusal to deal creates coercive pressures which are deemed as a matter of law to induce concert of action among adherent customers. ${ }^{48}$

From this principle, the court proceeds to reason that since the offense is called a conspiracy, civil liability is imposed on all members:

Characterization of the offense as conspiracy or combination implies civil liability for the violation attaching to all engaged in the forbidden undertaking, including customers. ${ }^{49}$

It can be seen from these statements that in extending liability to the dealers Klein duplicates the Parke, Davis abandonment of the conspiracy mens rea requirement. Merchants under the Klein theory may need to do no more than acquiesce in a resale price maintenance plan to be liable for damages. They may not need to have any part in its enforcement, any knowledge of how it is enforced, nor any control over the manner of its enforcement. 50

47 The extent to which the existence of these complaints may have influenced the judge's decision, and therefore caused him to base his result on a subconscious secondary boycott consideration is an important but unknowable factor. Some writers argue that the principal demand for resale price maintenance comes from the dealers rather than the manufacturer. See Bowman, The Prerequisites and Effects of Resale Price Maintenance, $22 \mathrm{U}$. CFI. L. REv. 825, 826-32 (1955). It would not seem, however, that this argument should be the basis for a legal presumption. Cf. Callmann, "Fair Trade" and Anti-Trust Law, $10 \mathrm{U}$. PrTT. L. Rev. 443, 466 (1949), where it is pointed out that dealer pressure may not indicate a true boycott, since self-interest would induce individual dealers to favor price-maintained goods whether or not their fellows did likewise. On other manufacturer-oriented motives for price maintenance, see Telser, Why Do Manufacturers Want Fair Trade? 3 J. L. \& EcoNomacs 86 (1960) (horizontal collusion or desire to maintain retail services); Wilson, Restrictive Practices, Competrmon, Cartels, and TheIr Regulation, 114, 141 (Miller ed. 1962) (introduction of new products). The "secondary boycott" approach has gained new respectability, however, by virtue of the concurring opinion of $\mathrm{Mr}$. Justice Brennan in White Motor Co. v. United States, 372 U.S. 253, 267 (1963): "If it were clear that the territorial restrictions involved in this case had been induced solely or even primarily by appellant's dealers and distributors, it would make no difference to their legality that the restrictions were formally imposed by the manufacturer rather than through inter-dealer agreement." Professor Turner has lent support to this approach also, Turner, supra note 28, at 698-99, $704-05$ (1962), and has even suggested that "it may also be that the distributors individually are "attempting to monopolize," id. at 704, thus plunging isolated dealers also into the allencompassing quagmire of illegality. $C f$. Johnson v. J. H. Yost Lumber Co., 117 F.2d 53, 61-62 (8th Cir. 1941), where lumber dealers inducing a manufacturer to cut off a price cutter were held liable in a case where the manufacturer was exonerated on the basis that he did not know of the conspiracy.

48206 F. Supp. 939.

$49 \mathrm{Id}$. at 940 .

50 The court seems troubled with its result, and acknowledges that the Supreme Court has never passed upon a similar extension of liability. It therefore attempts to fortify its logic 
The apparent abandonment of the mens rea requirement in Klein demonstrates the absurd results obtained by failure to differentiate between the object of the act and the Colgate exception. The court makes it clear that its result obtains because of the illegality of price-fixing: "The somewhat rigid and mechanical aspects of this result are wholly consistent with the inflexible Sherman Act proscription against price fixing in any form." 51 If Colgate were not still supposedly the law, there would be nothing illogical about the Klein result. Customers who maintained prices with knowledge of the price maintenance scheme must, of course, have intended to engage in price fixing, and therefore they would have intended to violate the act. So long, however, as Colgate is still considered law, the illegal act is not the price fixing itself, but rather fixing prices by methods exceeding Colgate protection. It is therefore only by intending that the manufacturer use methods exceeding Colgate protection that the customers can satisfy the mens rea requirement and become members of the conspiracy.

Klein should have reached an opposite result for several reasons. Most

with analogies to Interstate Circuit, Inc., v. United States, 306 U.S. 208 (1939); United States v. Masonite Corp., 316 U.S. 265 (1942); and United States v. United States Gypsum Co., 333 U.S. 364 (1948). These cases are found to be analogous to the facts before the court because they involve attempts by the manufacturer to control the price of goods after title has passed from his hands.

Interstate Circuit was concerned with establishing standards by which a horizontal conspiracy between merchants on the same level of distribution might be inferred. Masonite applied these principles to find a price fixing arrangement based upon a patent licensing scheme illegal, and U.S. Gypsum, also a patent licensing case, summarized the holdings of the previous two cases as follows: "[W]hen a group of competitors enters into a series of separate but similar agreements with competitors or others, a strong inference arises that such agreements are the result of concerted action." 333 U.S. at 394.

The agreements sought to be inferred in these cases are horizontal. In citing these cases the court loses sight of the distinction between horizontal and vertical arrangements. The concerted action standard appears inappropriate in a case involving a vertical arrangement and claiming to be governed by Parke, Davis. A Parke, Davis violation occurs as a result of the affirmative action of the organizer of the resale price maintenance plan. Concert of action by the dealers would tend to prove a horizontal conspiracy among them but would prove nothing about the manufacturer's methods. If the manufacturer acted within Colgate protection, the necessarily parallel conduct of the distributors in conforming to the resale price maintenance plan would not be illegal.

The court in Parke, Davis refrained from citing any of the "conscious parallelism" cases, cf. note 38 supra. Professor Turner has observed that Interstate Circuit (though not Masonite) suggests that no conspiracy exists where each distributor has an independent business reason for complying with the suggested price, and it seems unjust in any event, despite Masonite, to charge parties on the basis of parallel responses compelled by the threat of action from above or below. 75 HARV. L. REv. 698, 702 (1962). It is not clear in any event how this horizontal conspiracy, standing apart from vertical agreements, could be used to charge the manufacturer: Conscious parallelism seems a strained enough theory without using it to snare those not themselves engaged in paralleled conduct. But compare Levi, supra note 8 , at 323: "[T] he arrangement, organized by a manufacturer, of an illegal concert of action among its purchasers and with it, the manufacturer, would be both vertical and horizontal."

s1 206 F. Supp. at 940. 
obvious, of course, is that the confusion reigning in this branch of the law makes it impossible, especially for the small merchant without a legal staff, to find any standard by which to govern his conduct. An overruling of Colgate and a general ban on any kind of resale price maintenance would at least let the retailer know definitively where he stands, whatever the legitimacy of such a course in the light of the "combination" requirement of section 1,52 the new uncertainties which this course might open up for manufacturers ${ }^{53}$ and the countervailing policy suggested by other congressional enactments. 54

Moreover, it is difficult not to feel a sense of injustice at the thought of holding a small merchant liable for participation in a resale price maintenance plan when he may have been coerced into participating by a large supplier. ${ }^{55}$ Klein finds that even coerced participation in the conspiracy by the de-

$52 \mathrm{Cf}$. note 28 supra.

53 See text following note 61 infra.

${ }^{54} \mathrm{It}$ is to be noted that even the Robinson-Patman Act, the most far-reaching congressional interference with freedom of trade, expressly refrains from impairing the right to refuse to deal. "[N]othing... shall prevent persons engaged in selling goods, wares, or merchandise in commerce from selecting their own customers in bona fide transactions and not in restraint of trade." 49 Stat. 152 (1936), 15 U.S.C. \& 13(a) (1958). Though the legislative history of this proviso is ambivalent (see ROWE, PRICE DISCRIMINATION UNDER THE Robinson-Patman Act 46 (1962)), the Supreme Court has referred to it as "codifying ... Colgate." FTC v. Simplicity Pattern Co., 360 U.S. 55, 64 (1958). See also United States v. Bausch \& Lomb Optical Co., 321 U.S. 707, at 722 n.4 (1944). The plaintiff in Klein, by remarkable coincidence, had suffered an earlier legal set-back as a result of this proviso. See Klein v. Lionel Corp., 237 F.2d 13 (3d Cir. 1956). It may also be thought that since Colgate cannot be sent to its demise without straining the "contract, combination and conspiracy" limitation in Section 1 of the Sherman Act, minimal respect for the policy embodied in the McGuire and Miller-Tydings Acts and the state acts under them demands that a result be avoided which "only the clearest public policy can justify." Baran v. Goodyear Corp., 256 Fed. 571, 573 (S.D.N.Y. 1919). True, the federal statutes are only enabling statutes, and they have been held, in Bausch \& Lomb, not to alter the traditional per se rule. But it is one thing to say they do not alter existing law beyond their scope, and quite another to say they do not afford some guidance as to the appropriateness of new departures in the common law of antitrust. Cf. United States v. Hutcheson, 312 U.S. 219 (1941); Landis, Statutes and the Sources of Law, HARVARD LEgAl EsSAYS 213 (1934).

55 Sympathy for dealers who maintain prices is not roused in those cases where there is enough complicity on the part of the competing dealers to suggest secondary boycott (i.e., a refusal by the manufacturer to deal with one dealer which is instigated or coerced by competitors of the victim). An extreme example is Flintkote v. Lysfjord, 246 F.2d 368 (9th Cir.), cert. denied, 355 U.S. 835 (1957), in which the manufacturer had no resale price maintenance policy but was apparently forced by its dealers to cut off the price-cutting plaintiff. This case was tried on the theory of secondary boycott. More typical refusal to deal situations still find the dealers taking an active part. In Connecticut Importing Co. v. Continental Distilling Corp., 129 F.2d 651 (2d Cir.), cert. denied, 317 U.S. 664 (1942), the dealers and the manufacturer determined policy jointly, but the dealers were apparently the primary motivators of the cut-off. This case was dealt with as resale price maintenance in spite of the dominant role of the competing dealers. Klein stands at the far end of the spectrum from Flintkote in allowing recovery without aggressive action by competing dealers. For a sample of the fact situations possible in primary and secondary boycott, see Radiant Burners, Inc. v. People's Gas Light \& Coke Co., 364 U.S. 656 (1961); Klor's, Inc. v. Broadway-Hale Stores, Inc., 359 U.S. 207 (1959); Ballard Oil Terminal Corp. v. Mexican Petroleum Corp., 28 F.2d 91 (1st Cir. 1928). 
fendant dealers would have made no difference. 56 It is reasoned that since the manufacturer's motives in organizing the conspiracy make no difference in determining its legality, the customers' motives for participation make no difference in determining their liability. 57

This reasoning is dubious, for there does seem to be a theoretical basis for differentiating liability. It is open to question whether, as Klein asserts, a "rigid and mechanical" result is thoroughly in keeping with the act.58 Furthermore, parties coerced into participation in Sherman Act conspiracies have been treated leniently by the courts. Their status as parties to an illegal contract does not preclude their maintaining an action under the act when damaged by the conspiracy. 59

\section{CONCLUSION}

The above analysis reveals that application of conspiracy theory in resale price maintenance cases has been particularly loose, and there are clear indications in Klein that matters have reached the point where reconsideration is necessary. Advantages in favor of loose interpretation might conceivably have been thought to outweigh the disadvantages of confusion so long as it was reasonably certain that the effect would be primarily confined to Government

56 This is not, of course, a mens rea problem. Dealers might be perfectly aware that a resale price maintenance plan violated the Sherman Act, and that they were parties to an illegal conspiracy, even though they were forced to participate.

57206 F. Supp. at 940.

58 That reasonableness remains a criterion of interpretation for the Sherman Act has been reasserted as recently as White Motor Co. v. United States, 372 U.S. 253, 263 (1963).

59 Sola Elec. Co. v. Jefferson Electric Co., 317 U.S. 173 (1942); Nachman Spring-Filled Corp. v. Kay Mfg. Co., 139 F.2d 781 (2d Cir. 1943); American Cutting Alloys, Inc. v. General Elec. Co., 135 F.2d 502 (2d Cir. 1943); Connecticut Importing Co. v. Continental Distilling Corp., 129 F.2d 651 (2d Cir.), cert. denied, 317 U.S. 664 (1942); Connecticut Importing Co. v. Frankfort Distilleries, 101 F.2d 79 (2d Cir. 1939); Straus v. Victor Talking Machine Co., 297 Fed. 791 (2d Cir. 1924); Victor Talking Machine Co. v. Kemeny, 271 Fed. 810 (3d Cir. 1921); National Supply Co. v. Hillman, 57 F. Supp. 4 (W.D. Pa. 1944); Hartford-Empire Co. v. Glenshaw Glass Co., 47 F. Supp. 711 (W.D. Pa. 1942); Johnson v. Joseph Schlitz Brewing Co., 33 F. Supp. 176 (E.D. Tenn. 1940).

Particularly in point is Ring v. Spina, 148 F.2d 647 (2d Cir. 1945), where it is said: "It is well settled that where one party to an illegal contract acts under the duress of another the parties are not in pari delicto.... And in actions for triple damages under the Sherman Act a showing of economic duress ... has been held sufficient proof that the plaintiff is not a party to the monopoly .... . Further, there appears a definite tendency to hold those not actively engaged in promoting monopoly to be victims rather than participants in anti-trust violations." Id. at 652 . While Ring speaks in terms of monopoly, it relies upon conspiracy cases in which the same principles apply. E.g., Connecticut Importing Co. v. Continental Distilleries Corp., 129 F.2d 652 (2d. Cir.), cert. denied, 317 U.S. 664 (1942); Connecticut Importing Co. v. Frankfort Distilleries, 101 F.2d 79 (2d Cir. 1939). If one who is a member of a conspiracy through economic duress is not considered in pari delicto for the purposes of maintaining an action against the conspiracy, it may be reasoned by analogy that he should not be in pari delicto when an action is brought against him as part of the conspiracy. Arguments on this point are presented in Comment, The Nature of a Sherman Act Conspiracy, 54 Colum. L. REV. 1108, 1122-25 (1954). 
and FTC injunction suits directed against manufacturers. These could be expected to have been informed by counsel of the pitfalls in this branch of the law and to be powerful enough to control their own decisions on whether to embark upon policies of dubious legality. Klein, however, opens possibilities for enforcement of the treble damage provisions of the act at all levels of distribution and among all sizes of business entities. The need for rigor in defining standards of legality increases as the act approaches closer in its operation to "the question ... . whether two small exporting grocers should go to jail."60

Some commentators have suggested that problems in this area might be resolved by an overruling of Colgate. 61 But as we have seen, the language of section 1 of the act and the policy behind other congressional enactments make the legitimacy of this approach highly doubtful.62 Moreover, overruling Colgate would present the Court with difficult problems in the choice of a new standard. A simple declaration that refusals to deal undertaken to maintain resale prices are illegal will not resolve all problems. For a test in which legality is based upon the motive of the manufacturer would be, as Judge A. N. Hand suggested, virtually impossible to administer. ${ }^{63} \mathrm{~A}$ test which found illegality not in motive but in an effect on resale prices would call into question not merely price maintenance, but all forms of selective distribution. ${ }^{64} \mathrm{~A}$ test based on the market power of manufacturers has not hitherto been used in determining the legality of resale price maintenance, though the approach taken in the recent White Motor case 65 might support such a rule. The arguments which the Court in White thought might redeem closed territories have also be considered, by foreign observers at least, to redeem price maintenance in some instances.66 A test which would reject motive, effect, and market

60 Northern Securities Co. v. United States, 193 U.S. 197, 400 (1904) (Holmes, J., dissenting).

61 E.g., Turner, note 28 supra. But compare, e.g., Oppenheim, Selected Antitrust Developments, 15 A.B.A. ANTITRUST Section 37, 42-54 (1959).

62 See notes 28 and 54 supra.

63 See Baran v. Goodyear Tire \& Rubber Co., 256 Fed. 571, 573 (S.D.N.Y. 1919).

64 Manufacturers who restrict dealerships to those who perform needed services or maintain an adequate inventory would be vulnerable since the excluded "low service" dealers would usually charge less in reselling the product than authorized dealers. The widespread use of various forms of selected distribution would call into question the wisdom of such an "effect" rule. See Note, Restricted Channels of Distribution Under the Sherman Act, 75 HARV. L. REV. 795 (1962).

65 White Motor Co. v. United States, 372 U.S. 253, 263, 269 (1963). See also the merger and tying agreement cases there cited. The Supreme Court in referring to resale price maintenance spoke, however, of the practice's "lack of redeeming virtue," and seemed particularly impressed with the adverse effects of price maintenance on interbrand competition.

66 See as to encouraging entry of new products, Dalloz Recueil, 1953, 272-73, Decret-loi No. 53-704, Aug. 9, 1953 (statutory exemption in France); Wilson, supra note 47, at 141; as to maintenance of services see 8 \& 9 Eliz. 2, c. $45, \$ 14$ (Canadian statutory defense); Re Net Book Agreement, 1957, 1 Weekly L.R. 1347 (1962); ANDrEWs \& Frmay, FaIR Trade: Resale Price Manntenance Re-Examined 67-76 (1960). 
power as touchstones by making refusals to deal illegal except for the most basic of good business reasons, such as a customer's bad credit, would approach the standard applicable to public utilities. ${ }^{67}$ It may be doubted whether the economic interests at stake would be great enough to justify subjecting manufacturers to such close and continuing scrutiny.

Enough has been said to suggest that acceptance of proposals for undermining Colgate would enlarge, rather than remove, the present area of uncertainty in an area of antitrust law which affects a larger number of enterprises and transactions than most. So long as the central prohibitions against enforceable contracts and collective boycotts by manufacturers remain, "it would not be earthshaking, whichever direction the common law of anti-trust took with regard to resale price fixing." 68 One need not urge a retreat all the way to Dr. Miles, nor even concur in the view that there is no halfway house between $D_{r}$. Miles and a direct undermining of Colgate, ${ }^{69}$ to urge that minimal standards of fairness and certainty demand that the dictum, if not the holding, of Parke, Davis be repudiated. The unilateral activities of a manufacturer should not alone provide-as they did in Klein-a sufficient basis for finding a "conspiracy" between the manufacturer and dealers.

67 Professor Turner has noted that the standard would differ from that applicable to public utilities in that a manufacturer might not be obliged to take on new customers. But the practical significance of this qualification in the long run is open to doubt.

${ }^{68}$ Levi, The Parke, Davis-Colgate Doctrine: The Ban on Resale Price Maintenance, 1960 Sur. Cr. Rev. 258, 326.

${ }^{69}$ See Turner, supra note 28, at 686-87: "[A] distinction between a program of resale price maintenance effected by contracts and 'agreements' and one effected by threats of refusal to deal, is wholly untenable as a practical or logical matter unless 'agreement' is defined to exclude tacit or implied agreements." 